\title{
GPS technology to control of external demands of elite Brazilian female football players during competitions \\ Tecnología GPS para controlar las demandas externas de las jugadoras de fútbol brasileñas de élite durante las competiciones \\ Controle das demandas locomotoras externas de jogadoras da elite do futebol brasileiro através do uso do GPS durante competições \\ ${ }^{*}, * *$ Vitor Ayres Principe, ${ }^{* * *}$ Ignácio Antônio Seixas-da-Silva, ${ }^{*, * *}$ Rodrigo Gomes de SouzaVale, *Rodolfo de \\ Alkmim Moreira Nunes \\ *Rio de Janeiro StateU niversity (Brazil), ${ }^{* *}$ Estácio de SáU niversity (Brazil)
}

\begin{abstract}
This study aimed to deter mine the external load demands of elite Brazilian soccer players by position and playing time, using data from global positioning technology (GPS) at a data acquisition frequency of $10 \mathrm{~Hz}$ from a PolarTeam Pro. Twenty-three professional players from atop-flight Brazilian women's soccer team participated in the study. The women were $27.65 \pm 4.66$ years, $165.35 \pm 5.82 \mathrm{~cm}$ and 60.91 $\pm 5.34 \mathrm{~kg}$ D ata were collected during two competitions disputed simultaneously, theT he Sao Paulo State Championship and the Brazilian ChampionshipA1 series of 2019. Nine variables related to the external locomotor demand performed by the playersin thedisputed matches were analyzed. The statistical proceduresused werethetwo-wayAN OVA with Bonferroni post hoc for dataadjustment, and Cohen's effect size (d), with ap-value < .05 adopted to demonstratestatistical significance. Thesignificant differencesin the variablestotal distance, walking distance, jogging distance, running distance, Sprinting distance, acceleration zone 1, acceleration zone2, deceleration zone 1 and deceleration zone 2 were analyzed, and the results showed adecrease in the external locomotor demand of the loads during the matches played by these athletes. These results should be used to improve load control and adapt training practicesin women's soccer teams.
\end{abstract}

Keywords: Load Control, Female Football, G lobal Navigation Satellite System, GPS.

Resumen. Este estudio tuvo como objetivo determinar el comportamiento de las demandas de carga externade losjugadores de fútbol brasileños de élite por posición y tiempo de juego, utilizando datos de la tecnología de posicionamiento global (GPS) a una frecuencia de adquisición de datos de $10 \mathrm{~Hz}$ de un Polar Team Pro. Veintitrésjugadoras profesionales de un equipo de fútbol femenino brasileño de primer nivel participaron en el estudio. Lasmujerestenían $27.65 \pm 4.66$ años, $165.35 \pm 5.82 \mathrm{~cm}$ y $60.91 \pm 5.34 \mathrm{~kg}$ Los datosfueron recolectados durante dos competencias disputadas simultáneamente, el Campeonato del Estado de São Paulo y el Brasileño de la serieA1 de 2019. Se anal izaron nuevevariables relacionadas con la demanda externadelocomotoras real izadas por los jugadores en los partidos disputados. Los procedimientosestadísticos utilizados fueron el AN OVA de dosvías con Bonferroni post hoc parael ajuste de datos, yel tamaño del efecto de Cohen (d), con un valor dep < .05 adoptado para demostrar la significación estadística. Se analizaron las diferencias significativas en las variables distancia caminando, distanciadetrote, distancia corriendo, distanciade sprint, zonade aceleración 1, zonade aceleración 2, zona de desaceleración 1 y zonadedesaceleración 2, y los resultadosmostraron una disminución en la demandalocomotoraexternadelas cargas durante los partidos jugados por estosAtletas. Estos resultados deberían usarse para mejorar el control de cargay adaptar las prácticas de entrenamiento en los equipos defútbol femenino.

Palabras clave: Control de carga, Fútbol femenino, SistemaGlobal de Navegación por Satélite, GPS.

Resumo. 0 objetivo desteestudo foi determinar o comportamento dasdemandasde cargaexternadasjogadoras de futebol daelite do futebol brasileiro por posição e tempo dejogo, a partir dos dados datecnologiade posicionamento global (GPS), dafrequênciade aquisição dadosem $10 \mathrm{~Hz}$ Polar Team Pro.Vinteetrêsjogadorasde umaequipefutebol profissional da elite do futebol feminino brasileiro participaram desteestudo com idade de 27,65 \pm 4,66 anos, estatura: 165,35 $\pm 5,82 \mathrm{~cm}$ e peso: 60,91 $\pm 5,34 \mathrm{~kg}$. 0 s dados foram coletados durante 2 competições (Campeonato Paulistae do Campeonato Brasileiro sérieA1 de2019) de forma concomitante. Foram analisadas novevariáveis relacionadas com ademandalocomotora externa executadas pelasas jogadoras nas partidas disputadas. 0 sprocedimentos estatísticosutilizados foram a AN OVA de duas vias com post hoc de Bonferroni parao ajustamento de dados, o tamanho do efeito de Cohen (d), tendo valor de $p<.05$ foi adotado parademostrar asignificânciaestatística. As diferençassignificativas nas variáveis distânciatotal, distânciacaminhando, distância em trote, distânciacor rendo, distância em sprint, zonade aceleração 1, zona de aceleração. 2, zonade desaceleração 1 e zonade desaceleração 2 foram anal isadase os resultados encontrados apresentaram um decréscimo sobreademandalocomotora externadas cargasdurante as partidas dessasatletas. Esses resultados devem ser usados paramel horar o control ede carga eadaptar as práticas de treinamento em equipes defutebol feminino.

Palavras-chave: Controle de carga, Futebol feminino, SistemaG lobal de Navegação por Satélite, GPS.

Fecha recepción: 12-07-20. Fecha de aceptación: 07-10-20

Vitor Ayres Principe

vitorprin@gmail.com 


\section{Introduction}

Understanding the football match effect has on athletes is essential to optimizing performance being able to develop and implement effective interventions through the workload's quantification (Weston, 2018). Global Positioning System (GPS) technology can improve understanding of this phenomenon, when used to track activity on the playing field in open-air team sports (Cummins, O rr, O'Connor \& West, 2013).

In 2015, the International Council of the Football Association sanctioned the use of wear able technologies during official matches, or competitions. This made it possible to use small portable GPS units simultaneously with heart rate (HR) monitoring to characterize the external load and internal work performed (Bourdon et al. , 2017), as an integral part of the daily life of football clubs (Akenhead \& Nassis, 2016).

Initially, the implemented GPS technology was used exclusively for military or scientific purposes (Kaplan \& Hegarty, 2006; Dziadczyk, Zabierowski \& Napieralski, 2007). Thus, with its advancement, more extensive applications have emerged, such as use in team sports (Scott, Scott \& Kelly, 2016; Beato, Jamil \& Devereux., 2018). Thus, essential components can be quantified based on the information supported by technology, such as distances covered, speeds, accelerations, and decelerations (Akenhead, Harley \& Tweddle, 2016) or even movement pattern and physical impact of training sessions or games (Hennessy \& Jeffreys, 2018).

Despite its practical applications, the significant technological advance, and the massive amount of research using portable GPS devices (Rago, Brito, Figueiredo, Costa, Barreira, Krustrup \& Rabelo, 2019), certain problems have been found when they are used: (1) the reliability and validity of the device; (2) data collection and processing; (3) the satellite connection and itsaccuracy; and (4) data exclusion criteria(Malone, Lovell, Varley \& Coutts, 2017; Varley, Jaspers, Helsen $\&$ Malone, 2017).

These concerns are fundamental because the GPS calculates the athlete's position using trigonometry between satellites and the information accuracy depends on factors such as the number of satellites connected to each device and dilution of precision (DOP), which provides accuracy measure the signal determined by the position of the satellites in the sky (Dziadczyk et al. , 2007).

The most satellites distance in the sky provides the lowest triangulation error, consequently, the lowest DOP, while the closest satellites result in a significant triangulation er ror, with the highest DOP. If more than four satellites are used, a three-dimensional location is calculted (M oen, Pastor \& Cohen, 1997; Milbert, 2008).

Thus, it is feasible that professionals are more concerned with exploring the data collected from these devices, always aiming at a more sophisticated analysis, rather than understanding the validity and reliability of the system used. 0 ften, these professionals are conditioned by themarket instead of learning more about the accuracy of devices is known (Russell, Sparkes, Northeast, Cook, Love, Bracken \& Kilduff, 2016).

The use of GPS in professional football can facilitate the collection of variables necessary to control the internal and external load of players during training and/ or games (Buchheit, Manouvrier \& Morin, 2015; W hitehead, Till, W eaving \& J ones, 2018). The quantification of training and gameload can help decrease injuries and improve athletes' performance in team sports (Cumminsetal. , 2013; Milanoviæ, Sporiš̌, James, Trajkoviæ \& Ignjatoviæ, 2017). This may indicate that multiple and objective external and internal load variables should beincluded to accurately describethe physical and physiological demands of team sports in general and football in particular (Bendala, Vázquez, SuarezArrones \& Núñez, 2018).

Football has experienced a significant increase in the number of players participating in international competitions, professional leagues, and leisure leagues (Marqués-jiménez et al., 2017). Some studies suggest made inferences regarding gender from a small number of studies conducted on female athletes (Bradley, Dellal, M ohr, Castellano \& Wilkie, 2014). This could be due to game strategies, physical condition, and morphology, besides presenting a late detection ability and reduced training time according to the competitive level ( $\mathrm{Ca}$ ballero-Ruíz, Carrasco-Legleu, De León, CandiaLuján \& Ortiz-Rodríguez, 2019).

The physical and physiological loads of male football players, within the competitive context at different ages and levels, have been extensively examined in the literature for an extended period (Carling, Nelsen \& Reilly, 2008). 0 n the other hand, even with the increase in investigations within female football in recent years, there is little data available on such demands on female players (Datson, Hulton, Andersson, Lewis, Weston, Drust \& Gregson, 2014).

GPS studies to quantify these loads in international female football show higher HR values and more 
prolonged duration at high intensity during the game compared with training, which indicateshigher demands on the players' internal load during the game ( $0 \mathrm{hlsson}$, Berrg, Ljungberg \& Stålnacke, 2015).

A successful assessment of the physical loads imposed on football players requires an accurate assessment of both internal and external demands (Gaudino, Strudwick, Hawkins, Alberti, Atkinson \& Gregson, 2015). Studies using GPS devices have shown that professional football players cover distances of approximately $8 \pm 3 \mathrm{~km}$ during matches with a range of up to 119 meters per minute $\left(\mathrm{m}_{\mathrm{min}} \mathrm{min}^{-1}\right.$ ) (Bradley et al., 2014; Trewin, M eylan, Varley \& Cronin, 2018).

A study by Andersson, Randers, Heiner-Møller, Krustrup \& Mohr (2010), shows that high-intensity running represents up to $12 \%$ of the total distance. Midfield players tend to cover a longer distance, while defenders cover a shorter distance, both in total area covered and in high intensity running.

However, the distance covered at different speed ranges should not be the only consideration for assessing an athlete's workload. Specific low-intensity movements in football such as a) accelerations, b) decelerations, c) side and back runs, and even d) passes, are often neglected, leading to an erroneous estimation of the workloads performed by the players (Reche Soto, Cardona-N ieto, Diaz-Suarez, Bastida-Castillo, GomezCarmona, Garcia-Rubio \& Pino-O rtega, 2019). The workload of male and female playersal so differs between game positions, with midfield players achieving a higher load when compared to defenders or forwards (Park, Scott \& Lovell, 2019; Reche Soto et al., 2019; Strauss, Sparks \& Pienaar, 2019).

When analyzing the physical demands and match performance of femal efootball athletes, it's noticed that, when divided by activity sectors on the field of play, defenders performs fewer intervals of high-intensity running than midfielders and attackers, as well as fewer sprints than the attackers, showing that defenders have lower work rate than midfielders and attackers. In the physiological demands area, the comparison between women's and men's shows that they are similar, but the first one is characterized by less distance covered and higher speed intensity levels. Considering the technical events, for example, ball touches, time of possession of the ball, there's no gender difference during matches, but the female players can lose the ball possession and have a lower pass completion rates more than men players (Mohr, Krustrup, Andersson, Kirkendal \& Bangsbo, 2008; Bradley et al., 2014; M ilanoviæ et al., 2017).
This aspect differs from men's football, where a significant difference is perceived regarding maximum oxygen consumption when the squad is divided by game positions (Barbalho, Novoa \& Amaral, 2017).

Player load al so differs between positions in a football match, with midfielders reaching a higher load compared with forwards and defenders, thereby generally achieving a significantly higher relative total distance than that observed for defenders, and consequently, with a higher chance of fatigue (Dalen, Jørgen, Gertjan, Geir Havard \& UIrik, 2016).

Forwards act in the area of the field where more significant activity at high intensity is necessary, such as successive sprints and greater decision-making power. Improving the female athlete's ability to perform these activities should be emphasized in zerobic and resistance training programs, developing in the players a higher possibility of overcoming opponents, improving decisionmaking power, and creating more goal opportunities (Strauss et al., 2019).

The physiological stress experienced by players can result in fatigue that leads to loss of performance as such, performance is associated with appropriate recovery between matches and training (MarquésJiménez, Calleja-González, Arratibel, Delextrat $\&$. Terrados, 2017; Sinovas, Hernández \& Cerezal, 2020). Therefore, detailing the workload performed by players during acompetitive match providesa more exceptional view of the physical demands in female football, highlighting the characteristics related to performance and providing information to coaches and members of the coaching staff for more efficient and precise load control of each athlete (Strauss et al., 2019).

Thus, this study aimed to determine the behavior of elite female players' external load demands in Brazilian football, using data on position and playing time in two official competitions that coincide.

\section{Methods}

\section{Participants}

Twenty-three players from a top-level professional team in Brazilian female football participated in this study (mean \pm standard deviation; age: $27.65 \pm 4.66$ years; height: $165.35 \pm 5.82 \mathrm{~cm}$; weight: $60.91 \pm 5.34$ $\mathrm{kg}$ ). The study power found are $92 \%$. All players compete at national level, displaying experience both ingame and in training. The players were also classified into three groups according to their playing position: (I) seven defenders (DF): $30.29 \pm 4.89$ years; $163.75 \pm$ 
$5.74 \mathrm{~cm} ; 59.79 \pm 6.53 \mathrm{~kg}$; (II) nine midfielders (MF): $27.56 \pm 4.48$ years; $163.76 \pm 3.17 \mathrm{~cm} ; 60.28 \pm 3.08$ kg; and (III) seven forwards (FW ): $25.14 \pm 3.67$ years; $166.28 \pm 5.19 \mathrm{~cm} ; 61.25 \pm 5.87 \mathrm{~kg}$. All players were observed except when they were away by the coach staff for any injury or risk.

The participants were informed of the possible benefits and risks of the investigation before signing an institutionally approved informed consent form to participate in the study. The Human Research Ethics Committee of the Pedro Ernesto University Hospital (HUPE) of the State U niversity of Rio de aneiro (UERJ) approved the study (10529119.8.0000.5259) and the protocol was in accordance with the latest version of the Declaration of Helsinki (2013).

\section{Procedures}

All matches were held on pitches with official FIFA dimensions $(100 \times 75 \mathrm{~m})$, during the first 12 matches (phase 1) of the 2019 São Paulo State Championship and the last 11 matches of the 2019 A1 Brazilian Championship (group phase). Locomotor profiles of players during matches were obtained using GPS (Polar Team Pro, Polar Electro, Kempele, Finland).

The external loads during the matches of the first phase of the female São Paulo State Championship and the Brazilian female championship were acquired using a $10 \mathrm{~Hz}$ GPS sensor, recorded by a microelectromechanical sensor (MEMS). Each player was equipped with a GPS unit, coupled to a $200 \mathrm{~Hz}$ MEMS motion sensor (tri-axial accelerometer, gyroscope, and magnetometer). The monitoring device $(39 \mathrm{~g}, 36 \times 68 \times 13 \mathrm{~mm})$ was located on the chest, attached by a specific strap around the chest, with the sensor positioned over the entire xiphoid process (Polar Team Pro, Polar Electro, Kempele, Finland).

GPS devices have shown increasingly improved accuracy at a sampling frequency of up to $10 \mathrm{~Hz}$ (Malone et al., 2017), with no additional data-acquisition benefits from increasing the frequency (Scott et al., 2016). All devices were turned on 15 to 30 minutes before data collection to enable the acquisition of satellite signals and synchronize the device's clock with the satellite's atomic clock (Maddison \& Ni M hurchu, 2009). This procedure enabled the connection and acquisition of more than four satellites and a horizontal dilution of precision (HDOP) of less than 5, according to information from the manufacturer. The same unit was also used by each player in all matches to reduce the measurement error between units. The reliability of similar devices has been well documented in the literature (Silva, Esteves, Correia, Davids, Araújo \& Garganta, 2015; Clemente, Sarmento, Rabbani, Van Der Linden, Kargarfard \& Costa, 2019; Evangelio, GonzálezVíllora \& Clemente, 2019).

Polar Team Pro hardware and software were used to objectively record the mechanical aspects related to each player. Subsequently, the data were processed through the device web platform and exported in the text format regulated by RFC 4180 (comma-separated values - CSV).

\section{External load measures}

The speed zones were measured and defined by the manufacturer for the football modality were used to categorize the distance the player remained active (Zone

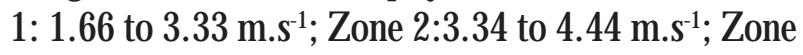
3: 4.45 to $5.55 \mathrm{~m} . \mathrm{s}^{1}$; Zone $4: 5.56$ to $6.38 \mathrm{~m} . \mathrm{s}^{1}$; Zone 5: > $6.39 \mathrm{~m} . \mathrm{s}^{-1}$ ). These speed-related zones were transformed from $\mathrm{km} . \mathrm{h}^{-1}$ to $\mathrm{m} \cdot \mathrm{s}^{-1}$ respecting that recommended by the International Measurement System (Système International d'U nités) (Débarbat \& Q uinn, 2019) with the purpose of facilitating the interpretation of the data presented.

The zones defined as standard by the manufacturer were al so used to categor ize acceler ation intensities (low: 0.50 to 0.99 m.s. $\mathrm{s}^{2}$; moderate: 1.00 to $1.99 \mathrm{~m} . \mathrm{s}^{2}$; high 2.00 to $2.99 \mathrm{~m} . \mathrm{s}^{-2}$; very high $>3.00 \mathrm{~m} . \mathrm{s}^{-2}$ ) and deceleration intensities (low: -0.99 to $-0.50 \mathrm{~m} . \mathrm{s}^{2}$; moderate: -1.99 to $-1.00 \mathrm{~m} . \mathrm{s}^{2}$; high -2.99 to $-2.00 \mathrm{~m} . \mathrm{s}^{2}$; very high $>-3.00 \mathrm{~m} . \mathrm{s}^{-2}$ ). Therefore, for analysis purposes, the activities performed in the matches were divided into the following categories: walking distance (WD): $\leq 3.33 \mathrm{~m} . \mathrm{s}^{1}$; jogging distance (JD): 3.34 to 4.44 m. $\mathrm{s}^{-1}$; running distance (RD): 4.45 to $5.55 \mathrm{~m} . \mathrm{s}^{-1}$; sprinting distance (SD): $\geq 5,55 \mathrm{~m} \cdot \mathrm{s}^{-1}$; acceleration number (ACc): $\geq 2.00 \mathrm{~m} . \mathrm{s}^{-1}$ and (IV) deceleration number (Des) $\leq-2.00 \mathrm{~m} . \mathrm{s}^{1}$ (Strauss et al., 2019).

In order to understand the influence of acceleration and consequent deceleration actions within a game, and whether a given acceleration action will generate an opposite deceleration action of the same quantity and magnitude, actions were categorized into two zones, acceleration zone 1 (A1) with $>2.00 \mathrm{~m} \cdot \mathrm{s}^{1}$ and zone 2 (A2) with 1.00 to $1.99 \mathrm{~m} . \mathrm{s}^{1}$ and deceleration zone 1 (D1) with values from -1.00 to $-1.99 \mathrm{~m} \cdot \mathrm{s}^{-1}$ and deceleration zone 2 (D2) with values $d »-2.00 \mathrm{~m} . \mathrm{s}^{1}$ according to (Ramos, Nakamura, Pereira, Junior, M ahseredjian, W ilke, Garcia \& Coimbra, 2017; Trewin et al., 2018). 


\section{Statistical Analysis}

The data were analyzed using the IBM SPSS Statistics 23 statistical program and presented as mean and standard deviation. The normality and homogeneity of the variance of the sample data were analyzed using the Kolmogorov-Smirnov and Levene tests. Bartlett's test was used to verify the sphericity of the data. Two-way ANOVA was used, having the position of the independent variables and playing time as factors, followed by Bonferroni's post hoc with data adjustment to identify possible differences in the study variables. Cohen's effect size (d) (Cohen, 1988), was cal culated to analyze the effect's magnitude. The magnitudes were interpreted qual itatively using the limits: insignificant $(<.2)$, small $(0.2-0.6)$, moderate $(0.6-1.2)$, large $(1.2-2.0)$, very large $(2.0-4.0)$ and almost perfect (> 4.0) (Hopkins, M arshall, Batterham \& Hanin, 2009). The value of $p<.05$ was adopted for statistical significance.

\section{Results}

The physical matches variables of external demands between different positions are shown in Table 1. It can be seen that for each position on the field of play, different variables have no normality and homogeneity according to the Kolmogorov-Smirnov test. Thus, it is observed

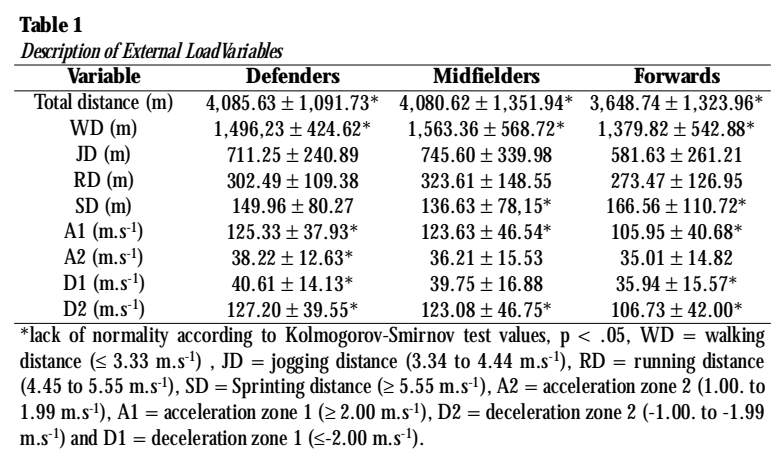

that total distance, walking distance, acceleration in zone 2, that is, from 1.00 to $1.99 \mathrm{~m} . \mathrm{s}^{1}$, and deceleration in zone $2\left(-1.00\right.$ to $\left.-1.99 \mathrm{~m} . \mathrm{s}^{1}\right)$ are the only variables that demonstrate absence of normality and homogeneity in all three positions of the playing field. To demonstrate this behavior, analysis of variance (ANOVA) with Bonferroni's adjustment was used to treat the collected data.

Table 2 shows the external load demands during official games divided into two groups, these being the 1st and 2nd half of matches for the different game positions described in this study. Thus, we highlight the statistical difference between each position and the magnitude of the effect size (d) presented, as well as the $95 \%$ confidence interval for .

W hen comparing defenders and forwards, the magnitude of the effect size was moderate for jogging distance, acceleration zone 2 , and deceleration zone 2 . In the comparison between midfielders and forwards, the moderate effect size appears only for acceleration zone 1, even though it does not show any significant difference by the method used. It is also noteworthy that when comparing defenders and midfielders, the effect size is approximately $89 \%$ insignificant in all the studied samples.

Highlights the significant differences in Table 2 for each game period. In the second half of the matches, we found the most significant differences in thetotal distance variables (between defenders and midfielders; midfielders and forwards), walking distance (between Defenders and Forward; Midfielders and Forwards), jogging distance (between midfielders and forwards), running distance (between midfielders and forwards), acceleration zone 1 (between defenders and forward; midfielders and forwards), acceleration zone 2 (between defenders and forward), deceleration zone 1 (between defenders and Forward) and deceleration zone 2

Table 2

\begin{tabular}{|c|c|c|c|c|c|c|c|}
\hline Variable & Time & Defenders (DF) & Midfielders (MF) & Forwards (FW) & $\begin{array}{c}\text { Cohen (d) }[\mathrm{Cl} 195 \%] \\
\text { DF to M F }\end{array}$ & $\begin{array}{c}\text { Cohen (d) }[\mathrm{Cl} 95 \%] \\
\text { DF to FW }\end{array}$ & $\begin{array}{c}\text { Cohen (d) }[\mathrm{Cl} 95 \%] \\
\text { MF to FW }\end{array}$ \\
\hline \multirow{2}{*}{ Total Distance (m) } & 19 & $4,347.23 \pm 1,123.64$ & $4,596.21 \pm 1195.95$ & $4,464,50 \pm 1040.26$ & -0.214 (IE) $[-0.51 ; 0.09]$ & -0.108 (IE) $[-0.44 ; 0.23]$ & -0.669 (IE) $[-0.99 ; 0.34]$ \\
\hline & 20 & $3,859.29 \pm 1,016.21 \partial$ & $3,647.15 \pm 1327.62 \rho$ & $3,137,86 \pm 1226.21$ & 0.177 (IE) $[-0.10 ; 0.45]$ & 0.637 (IE) $[0.34 ; 0.93]$ & 1.205 (ME) $[0.91 ; 1.49]$ \\
\hline \multirow{2}{*}{$W D(m)$} & 10 & $1,609,44 \pm 449.71$ & $1,785,37 \pm 520.64$ & $1,707,32 \pm 475.54$ & -0.359 (IE) $[-0.66 ;-0.05]$ & -0.212 (IE) $[-0.55 ; 0.12]$ & 0.155 (IE) $[-0.17 ; 0.47]$ \\
\hline & 20 & $1,398,28 \pm 377.47 \sigma$ & $1,376.71 \pm 541.61 \rho$ & $1,174,72 \pm 479.64$ & 0.045 (IE) $[-0.23 ; 0.32]$ & 0.515 (SE) $[0.22 ; 0.80]$ & 0.393 (SE) $[0.12 ; 0.66]$ \\
\hline \multirow{2}{*}{$J D(m)$} & 10 & $764.03 \pm 259.51$ & $849.25 \pm 336.94 \rho$ & $716.97 \pm 266.12$ & -0.280 (IE) $[-0.58 ; 0.02]$ & 0.179 (IE) $[-0.16 ; 0.51]$ & 0.000 (IE) $[-0.32 ; 0.32]$ \\
\hline & 20 & $665.58 \pm 214.71$ & $658.45 \pm 318.70 \rho$ & $496.87 \pm 220.15$ & 0.026 (IE) [-0.25; 0.30$]$ & 0.775 (ME) $[0.31 ; 0.86]$ & 0.583 (SE) $[0.31 ; 0.86]$ \\
\hline $\mathrm{RD}(\mathrm{m})$ & 10 & $319.52 \pm 115.65 \partial$ & $368.02 \pm 150.37$ & $326.56 \pm 130.38$ & -0.357 (IE) $[-0.66 ;-0.05]$ & -0.058 (IE) $[-0.39 ; 0.28]$ & 0.290 (SE) $[-0.03 ; 0.61]$ \\
\hline \multirow{2}{*}{$\mathrm{SD}(\mathrm{m})$} & $\begin{array}{l}20 \\
10\end{array}$ & $\begin{array}{c}287.76 \pm 102.03 \\
163.96 \pm 83.29\end{array}$ & $\begin{array}{c}286.27 \pm 136.85 \rho \\
157.74 \pm 88.26 \rho\end{array}$ & $\begin{array}{l}240.21 \pm 113.26 \\
197.32 \pm 113.67\end{array}$ & $\begin{array}{l}0.012 \text { (IE) }[-0.27 ; 0.29] \\
0.072(\mathrm{IE})[-0.23 ; 0.37]\end{array}$ & $\begin{array}{c}0.440 \text { (SE) }[0.15 ; 0.73] \\
-0.340 \text { (IE) }[-0.68 ; 0.00]\end{array}$ & $\begin{array}{r}0.364 \text { (SE) }[0.09 ; 0.64] \\
-0.400 \text { (IE) [-0.72; }-0.071\end{array}$ \\
\hline & 20 & $137.84+75.97$ & $118.89+63.68$ & $147.29+104.88$ & 0.273 (SE) [-0.01: 0.55$]$ & -0.102 (IE) [-0.39:0.18] & -0.332 (IE) [-0.60; -0.06$]$ \\
\hline \multirow{2}{*}{$\mathrm{A} 1\left(\mathrm{~m} . \mathrm{s}^{-1}\right)$} & 10 & $132.84 \pm 38.30$ & $138.54 \pm 43.09$ & $127.68 \pm 36.09$ & -0.139 (IE) $[-0.44 ; 0.16]$ & 0.138 (IE) [-0.20; 0.47$]$ & 0.268 (SE) $[-0.05 ; 0.59]$ \\
\hline & $2^{0}$ & $118.82 \pm 36.58 \sigma$ & $111.10 \pm 45.80 \rho$ & $92.34 \pm 37.49$ & 0.184 (IE) $[-0.10 ; 0.46]$ & 0.714 (ME) $[0.42 ; 1.01]$ & 0.445 (SE) $[0.17 ; 0.72]$ \\
\hline \multirow{2}{*}{$\mathrm{A} 2\left(\mathrm{~m} \cdot \mathrm{s}^{-1}\right)$} & 10 & $41.08 \pm 12.89$ & $41.08 \pm 15.09$ & $41.34 \pm 14.31$ & 0.000 (IE) $[-0.30 ; 0.30]$ & -0.019 (IE) $[-0.35 ; 0.32]$ & -0.018 (IE) $[-0.34 ; 0.30]$ \\
\hline & 20 & $35.75 \pm 11.92$ & $35.75 \pm 14.74$ & $31.05 \pm 13.79$ & 0.000 (IE) $[-0.28 ; 0.28]$ & 0.362 (SE) $[0.07 ; 0.65]$ & $0.692(\mathrm{ME})[0.41 ; 0.97]$ \\
\hline \multirow{2}{*}{$\mathrm{D} 1\left(\mathrm{~m} . \mathrm{s}^{1}\right)$} & 10 & $44.05 \pm 13.51$ & $46.65 \pm 16.29$ & $44.16 \pm 14.78$ & -0.008 (IE) $[-0.34 ; 0.33]$ & -0.172 (IE) $[-0.47 ; 0.13]$ & 0.158 (IE) [-0.16;0.48] \\
\hline & 20 & $37.63 \pm 14.04 \sigma$ & $33.96 \pm 15.15$ & $30.79 \pm 13.80$ & 0.250 (SE) [-0.03; 0.53$]$ & 0.492 (SE) $[0.20 ; 0.78]$ & 0.218 (SE) $[-0.05 ; 0.49]$ \\
\hline \multirow{2}{*}{$\mathrm{D} 2\left(\mathrm{~m} . \mathrm{s}^{1}\right)$} & 10 & $134.13 \pm 38.96$ & $135.62 \pm 42.31$ & $128.98 \pm 36.12$ & -0.036 (IE) $[-0.34 ; 0.26]$ & 0.137 (IE) $[-0.20 ; 0.47]$ & 0.166 (IE) $[-0.16 ; 0.49]$ \\
\hline & $2^{0}$ & $121.20 \pm 39.28 \sigma$ & $112.54 \pm 47.86 \rho$ & $92.80 \pm 39.47$ & 0.026 (IE) $[-0.25 ; 0.30]$ & 0.721 (ME) $[0.42 ; 1.01]$ & 0.394 (SE) $[0.12 ; 0.66]$ \\
\hline
\end{tabular}


(between defenders and forward; midfielders and forwards).

In the first half of the matches, the differences between defenders and midfielders in the running distance variable and two differences between midfielders and forwards (walking and sprinting distance). Thus, these differences between the positions and each match period are related by athletes grouping of the three positions (defenders, midfielders, and forwards), where a new distribution can change the whole presented data in Table 2.

\section{Discussion}

The external physical locomotor demands demonstrated through the acquisition of GPS data in 23 official matches of female football players showed that the defenders covered a greater total distance with a difference of approximately $5.01 \mathrm{~m}$ to midfielders. This characteristic of the analyzed team is different from the findings of (Strauss et al., 2019), where midfield player s cover agreater distance in matches, as previously shown by Andersson et al. (2010) in international players.

W hen observing the absolute values of total distance, it can be seen that the players present in this study had values in units of thousands (1000), as per the studies by Strauss et al. (2019) using GPS with 30 sub-elite female athletes (age: $22.8 \pm 2.4$ ). This differs from the 17 international level female athletes (age: $27.0 \pm 1.0$ ) from Sweden and Denmark in the study by Andersson et al. (2010) using video analysis, where the absolute values are described in units of ten thousands (10000).

The study by Ramos et al. (2017) with U 20 athletes from the Brazilian female national team, presents ascale of values similar to that found, for example, in the average total distance of the defenders, with $8,201.60 \mathrm{~m}$ and this study being $8,206.52 \mathrm{~m}$. On the other hand, when the data are compared with a senior Brazilian female team, as described in the study by Ramos et al. (2019) defenders have an average of $10,003.40 \mathrm{~m}$ in absolute values, which is similar to that found by Andersson et al. (2010) also in senior teams. Thus, from the use of other variables for a more in-depth analysis, differences between teams and competitions can be identified around the world.

The playerswho act in defense, in midfield, and attack cover average distances $(4,085.63 \mathrm{~m} ; 4,080.62 \mathrm{~m}$; $3,648.74 \mathrm{~m}$ ) more significant than those presented in the studies by (Dalen et al., 2016; Park et al., 2019; Reche-Soto et al., 2019; Strauss et al., 2019). However, individualizing the speed thresholds results does not add value in determining football activity response in elite players, according to (Scott \& Lovell, 2018). These show that total distance is a variable relative to the match and the opponent faced in each competition, requiring variables that determine the context for comparison purposes.

In the present study, in Table 2, the total distance only showed significant results in the second half of the matches, when comparing athletes in the defensive and attacking positions ( $p<.001)$, according to the study in female football (Ramos et al., 2017), central defenders showed a probability of almost individual differences in all tested variables. (M ohr et al., 2008), that found no differences in the total distance variable when observed between the playing position compared to both genders. Therefore, understanding the game model of the teams to promote a better definition of the players distribution on the field of play can bring an improvement to the data analysis of athletes who work in the midfield and the attack (M oreira, Arroyo \& Praça, 2020).

The activity demands for the speed zones showed a significant difference in the 1st half of the matches between midfielders and forwards for the variables JD $(p=.010)$ and SD $(p=.018)$ and between defenders and midfielders for RD ( $p=.038$ ). In the 2 nd half, the variables JD and RD between midfielders and forwards show $p<.001$ and $p=.025$, respectively, but with a small magnitude of effect. Thus, it can be understood that these isolated variables cannot describe sports activity during match times, as found by (Strauss et al., 2019).

The acceleration variable in zone 2 does not show any significant difference in any of the positions in either half of the game, while deceleration in zone 1 shows a difference in the actions between Defenders and Forwards $(p=.004)$ in the second half of the game. However, the actions related to acceleration zone 1 and deceleration zone 2 reflected the significance of actions between defendersand forwards $(p=.004)$ and between midfielders and forwards $(p=.004)$ in the second half of the matches, as per studies by (Trewin et al., 2018; Ramos et al., 2019;).

In the game model presented, which is characterized by progression up the field of play with the maintenance of ball possession, defenders presented ahighly significant number of accelerations and decelerations, with an average of 38.22 accelerations above $\geq 2.00 \mathrm{~m} . \mathrm{s}^{1}$ and 40.61 decelerations below $\leq-2.00 \mathrm{~m} . \mathrm{s}^{1}$, showing a more significant number of these actions than other athletes 
from other positions. According to the findings of ( $R$ a mos et al., 2017), where the number of accelerations $\geq$ $2.00 \mathrm{~m} . \mathrm{s}^{1}$ and decelerations $\leq-2.00 \mathrm{~m} . \mathrm{s}^{1}$ were most likely more significant in the first half compared to the second half. This may be related to the support of the flanks that were included in this category for study purposes and are players who continuously need to accelerate and decelerate during a match.

\section{Study Limitations}

Also, the use of micro-sensor technology that makes it possible to quantify the external locomotor demands of athletes through metrics originating from GPS is suggested based on the variability of the observed measures. However, it is advisable for members of the coaching staff to examine their players' individual variation whenever possible, in order to makeinferences regarding changes in performance between the observed matches.

Therefore, we understand the lack of transparency of the company that supplies the device as a limitation of this study, as the company does not present the number of satellites or the horizontal precision value (HDO P) at the time of data acquisition; also, how the positions of defense, midfield and attack are classified is a further limitation.

\section{Conclusion}

According to this study, this study was unable to determine whether the behavior of the external load demands of players is influenced because of the competitions occur concomitantly. In general, it is observed a decrease in the external locomotor demand for loads during matches with professional Brazilian femal e football players. These differences were observed using playing field positions and analyzed according to each variable's behavior during two simultaneous competitions. However, the need for a more accurate investigation to affirm this proposition.

Based on the results, there is a need to improve the components of physical fitness specific to the games of these players, especially when there is a decrease in the means of the variables among all positions during the different periods of the matches in the competitions. This decrease presents moderate magnitudes between defendersand midfielders, and midfieldersand forwards, which may be associated with physiological deterioration of the players during game halves and competitions being played concurrently.

Thus, frequent evaluation of the players where it is possible to measure components such as (a) concentric and eccentric strength of the muscles of the lower limbs, and (b) tests that can simulate agility, speed, change of direction, and decision making of the athletes, are essential for the deployment of more assertive al gorithms from data analysis. This greater assertiveness using data from external loads from GPS and tests organized throughout the season represents a different view to improving the components of these players' physical fitness.

This information is relevant so that coaches and technical staff can discern the physical standards for each position. The study showed that there are significant differences between the positions of defense, midfield, and attack among professional female football players. The conclusions of this study provided a theoretical justification to explain the level of performance achieved by the players, which can be manipulated by tasks in training that provide relevant implications for improving physical interactions during matches.

\section{Declaration of conflict of interests}

The authors declare no potential conflicts of interest with the research, authorship, and/ or publication of this article.

\section{Funding}

This work was supported by the Carlos Chagas Filho Foundation for Research Support of the State of Rio de Janeiro under Grant [number E-26/ 202.638/ 2018].

\section{References}

Akenhead, R, \& Nassis, G. P. (2016). Training load and player monitoring in high-level football: Current practice and perceptions. International Journal of Sports Physiology and Performance, 11(5), 587-593. https:/ / doi.org/ 10.1123/ ijspp. 2015-0331

Akenhead, Richard, Harley,J.A., \&Tweddle, S. P. (2016). Examining theexternal training load of an english premier leaguefootball team with special reference to acceleration. Journal of Strength and Conditioning Research, 30(9), 2424-2432. https:// doi.org/ 10.1519/ JSC.0000000000001343

Andersson, H. A., Randers, M. B., Heiner-M øller, A. , Krustrup, P., \& Mohr, M. (2010). Elite female soccer players perform more high-intensity running when playing in international gamescompared with domesticleaguegames. Journal of Strength 
and Condition, 24(4), 912-919.

Barbalho, M. de S. M., Novoa, H. J. D., \& Amaral, J. C. (2017). Consumo máximo de oxigênio (vo2) em atletas de futebol profissional de diferentes posições de jogo. Revista Brasileria de Futsal e Futebol, 19(32), 37-41.

Beato, M., Jamil, M., \& Devereux, G. (2018). Reliability of internal and external load parameters in recreational football (soccer) for health. Research in Sports Medicine, 26(2), 244-250. https:/ / doi.org/ 10.1080/ 15438627.2018.1431532

Bendala, F.J.T.,Vázquez, M. A. C., Suarez-Arrones, L.J., \& N vuñez, F. J. (2018). Comparison of external load in high speed actionsbetween friendly matches and training sessions Comparación de carga externa en las acciones de alta velocidad en partidos amistosos y sesiones de entrenamientos. 4.

Bourdon, P. C., Cardinale, M., Murray, A., Gastin, P., Kellmann, M., Varley, M. C., Gabbett, T. J., Coutts, A. J., Burgess, D. J., Gregson,W., \& Cable, N. T. (2017). M onitoringathletetraining loads: Consensus statement. International Journal of Sports Physiology and Performance, 12, 161-170. https:/ / doi.org/ 10.1123/ IJ SPP. 2017-0208

Bradley, P S, Della, A., Mohr, M., Castellano, J., \& Wilkie, A. (2014). Gender differences in match performance characteristics of soccer players competing in the UEFA Champions League. Human Movement Science, 33(1), 159171. https:/ / doi.org/ 10.1016/ j.humov.2013.07.024

Bucheit, M., Manouvrier, C., Cassirame,J., \& M orin, J.-B. (2015). M onitoring Locomotor Load in Soccer: Is M etabolic Power, Powerful? International Journal of SportsM edicine, 36(14), 11491155. https: / doi.org/ 10.1055/ s-0035-1555927

Caballero-Ruíz,A., Carrasco-Legleu, C. E., DeLeón, L. G., Candia Luján, R., \& O rtiz-Rodríguez, B. (2019). Somatotipo demujeres futbolistas universitarias por posición en el terreno de juego. Retos, 36, 228-230.

Carling, C., Bloomfield,J., N elsen, L., \& Reilly,T. (2008).TheRole of Motion Analysis in Elite Soccer: Contemporary Performance M easurement Techniques andWork Rate Data. Sports Medicine, 38(10), 839-862. https:/ / doi.org/ 10.2165/ 00007256-200838100-00004

Clemente, F. M., Sarmento, H., Rabbani, A., Van Der Linden, C. M. I. N., Kargarfard, M., \& Costa, I. T. (2019). Variations of external load variables between medium- and large-sided soccer games in professional players Research in Sports M edicine, 27(1), 50-59. https:// doi.org/ 10.1080/ 15438627.2018 .1511560

Cohen, A. (1988). Statistical Power Analysis for the Behavioral Sciences (2nd ed.). Routledge.

Cummins, C., Orr, R., O 'Connor, H., \&West, C. (2013). Global Positioning Systems (GPS) and Microtechnology Sensors in Team Sports: A Systematic Review. Sports Medicine, 43(10), 1025-1042. https: / / doi.org/ 10.1007/ s40279-013-00692

Dalen, Terje, Jørgen, I., Gertjan, E., Geir Havard, H., \& U Irik,W. (2016). Player Load, Acceleration, and Deceleration During Forty-Five Competitive Matches of Elite Soccer: Journal of
Strength and Conditioning Research, 30(2), 351-359. https:/ / doi.org/ 10.1519/ JSC.0000000000001063

Datson, N., Hulton, A., Andersson, H., Lewis, T., Weston, M., Drust, B. \& \& Gregson,W. (2014). Applied physiology of female soccer: An update. SportsM ediane, 44(9), 1225- 1240. https:/ / doi.org/ 10.1007/ s40279-014-0199-1

Débarbat, S., \& Q uinn,T. (2019). Lesoriginesdu systèmemétrique en France et laConvention du mètre de 1875, qui a ouvert la voieau Systèmeinternational d'unitésetàsarévision de2018. Comptes Rendus Physique, 20(1-2), 6-21. https:/ / doi.org/ 10.1016/ j.crhy.2018.12.002

Dziadczyk, E., Zabierowski,W., \& N apieralski,A. (2007). Satellite Navigation System GPS. 2007 9th International Conference-The Experience of Designing and Applications of CAD Systems in Microelectronics, 504-506. https:/ / doi.org/ 10.1109/ CADSM. 2007.4297633

Evangelio, C., Sierra Díaz, M. J., González-Víllora, S. \& \& Clemente, F. M. (2019). 'Four goals for three players': U sing 3 vs. 3 small-sided gamesat school. Human M ovement, 20(4), 68-78. https:/ / doi.org/ 10.5114/ hm.2019.85096

Gaudino, P., laia, F., Strudwick, A. J., Hawkins, R. D., Alberti, G., Atkinson, G., \& Gregson, W. (2015). Factors influencing perception of effort ( session-RPE) during litesoccer training International Journal of Sports Physiology and Peformance.

Hennessy, L., \& Jeffreys, I. (2018). The Current Use of GPS, Its Potential, and Limitations in Soccer: Strength and Conditioning Journal, 40(3), 83-94. https:// doi.org/ 10.1519/ SSC. 0000000000000386

Hopkins, W. G., Marshall, S. W., Batterham, A. M., \& Hanin, J. (2009). Progressive statistics for studies in sports medicine and exercise science. Medicine and Science in Sportsand Exercise, 41(1), 3-12. https:// doi.org/ 10.1249/ MSS.0b013e31818cb278

Kaplan, E. D., \& Hegarty, C. (Eds.). (2006). Undersanding GPS: Principles and applications (2nd ed). Artech House.

Maddison, R., \& Ni Mhurchu, C. (2009). Global positioning system: A new opportunity in physical activity measurement. International Journal of Behavioral N utrition and Physical Activity, 6 , 73. https:/ / doi.org/ 10.1186/ 1479-5868-6-73

Malone, J. J., Lovell, R., Varley, M. C., \& Coutts, A. J. (2017). Unpacking the black box: Applicationsand considerations for using gps devicesin sport. International Journal of SportsPhysiology and Performance, 12, 18-26. https:/ / doi.org/ 10.1123/ ijspp. 2016-0236

Marqués-jiménez, D., Calleja_González, J.,Arratibel, I., Delextrat, A., \& Terrados, N. (2017). Fatigue and Recovery in Soccer: Evidenceand Challenges The0 pen SportsSciencesJ ournal, 10(1), 52-70. https:/ / doi. org/ 10.2174/ $1875399 \times 01710010052$

Milanoviæ, Z., Sporiš̌, G. , James, N., Trajkoviæ, N., Ignjatoviæ,A., Sarmento, H., Trecroci, A., \& Mendes, B. M. B. (2017). Physiological Demands, Morphological Characteristics, Physical A bilitiesand Injuries of Female Soccer Players. Journal of Human Kinetics, 60(1), 77-83. https: / / doi. org/ 10.1515/ 
hukin-2017-0091

Milbert, D. (2008). Dilution of Precision Revisited. Navigation, 55(1), 67-81. https:// doi. org/ 10.1002/ j.21614296.2008.tb00419.x

Moen, R., Pastor,J., \&Cohen,Y. (1997).Accuracy ofGPSTelemetry Collar Locations with Differential Correction. The Journal of Wild life M anagement, 61(2), 530. https:/ / doi.org/ 10.2307/ 3802612

Mohr, M., Krustrup, P.,Andersson, H., Kirkendal, D., \& Bangsbo, J. (2008). MatchActivities of EliteWomen Soccer Players at Different Performance Levels: Journal of Strength and Conditioning Research, 22 (2), 341-349. https: / / doi.org/ 10.1519/ JSC.0b013e318165fef6

Moreira, P., Sousa, R., Morales, J. C., Greco, P., Arroyo, M. P., \& Praça, G. (2020). Comportamiento táctico de jugadores de fútbol de diferentes posiciones, durante una temporada deportiva (Tactical behaviour of soccer players from different plajing positionsthroughoutaseason). Retos, (39), 1-6. https:/ / doi.org/ 10.47197/ retos. v0i39.75970

O hlsson, A., Berg, L. , Ljungberg, H., Söderman, K. \& \& Stånacke, B.-M. (2015). Heart Rate Distribution duringTraining and a Domestic League Game in Swedish Elite Female Soccer Players Annals of Sports Medicine and Research, 2(4), 1025.

Park, L. A. F., Scott, D., \& Lovell, R. (2019). Velocity zone classification in elitewomen'sfootball:W heredo wedraw the lines? Science and Medicine in Football, 3(1), 21-28. https: / doi.org/ 10.1080/ 24733938.2018.1517947

Rago,V., Brito, J., Figueiredo, P., Costa, J., Barreira, D., K rustrup, P., $\&$ Rebelo,A. (2019). Methodsto collect and interpretexternal training load using microtechnology incorporating GPS in professional football: A systematic review. Research in Sports Medicine, 00(00), 1-22. https:/ / doi. org/ 10.1080/ 15438627.2019.1686703

Ramos, Guilherme P., Nakamura, F., Pereira, L., Junior, W., Mahseredjian, F.,W ilke, C., Garcia, E., \& Coimbra, C. (2017). Movement PatternsofaU-20 NationalWomen'sSoccerTeam during Competitive Matches: Influence of Playing Position and Performancein the First Half. International Journal of Sports M edicine, 38(10), 747-754. https:/ / doi.org/ 10.1055/ s0043-110767

Ramos, GuilhermeP., Nakamura, F.Y., Penna, E. M.,W ilke, C. F., Pereira, L.A., Loturco, I., Capelli, L., M ahseredjian, F., SilamiGarcia, E., \& Coimbra, C.C. (2019).Activity Profilesin U17, U20, and SeniorWomen ${ }^{1 / 4} / 4$ Brazilian National SoccerTeams During International Competitions: AreThere Meaningful Differences? Journal of Strength and Conditioning Research, 33(12), 3414-3422. JSC. 0000000000002170

RecheSoto, P., CardonaNieto, D., DiazSuarez,A., BastidaC astillo, A., Gomez Carmona, C., GarciaRubio, J., \& Pino O rtega, J. (2019). Player load and metabolic power dynamics as load quantifiers in soccer. Journal of Human Kinetics, 69(1), 259269. https:/ / doi.org/ 10.2478/ hukin-2018-0072

Russell, M., Sparkes, W., N or theast, J., Cook, C. J., Love, T. D.,
Bracken, R. M., \& Kilduff, L. P. (2016). Changesin acceleration and deceleration capacity throughout professional soccer match-play.journal of Strength and Conditioning Research, 30(10), 2839-2844.

https:/ / doi.org/ 10.1519/ JSC. 0000000000000805

Scott, D. \& L Lovell, R. (2018). Individualisation of speed thresholds doesnot enhancethedose responsedetermination in football training Journal of Sports Sciences, 36(13), 1523-1532. https:/ / doi.org/ 10.1080/ 02640414.2017.1398894

Scott, M., Scott,T., \& Kelly,V. (2016).TheValidity and Reliability of Global Positioning Systems in Team Sport: A Brief Review. Journal of Strength and Conditioning Research, 30(5), 1470-1490. https: / / doi.org/ 10.1519/ JSC.0000000000001221

Silva, P., Esteves, P., Correia,V., Davids, K., A raújo, D., \& Garganta, J. (2015). Effects of manipulations of player numbers vs. Field dimensionson inter-individual coordination duringsmall-sided games in youth football. International Journal of Performance Analysisin Sport, 15(2), 641-659. https:/ / doi.org/ 10.1080/ 24748668.2015.11868821

Sinovas, M. C., Hernández, M. L. R., \& Cerezal, A. B. (2020). Epidemiology of injuries in young Spanish soccer players according to the playing positions (Epidemiologíade laslesiones en futbolistas jóvenes españoles según la demarcación). Retos, 38, 459-464. https:// doi.org/ 10.47197/ retos. v38i38.74649

Strauss, Anita, Sparks, M., \& Pienaar, C. (2019a).The Use of GPS Analysisto $Q$ uantify the Internal and External $M$ atch Demands of Semi-EliteLevel FemaleSoccer PlayersduringaTournament. Journal of Sports Science and Medicine, 18(1), 73-81.

Trewin, Joshua, Meylan, C., Varley, M. C., \& Cronin, J. (2018). The match-to-match variation of match-running in elite female soccer. Journal of Scienceand M edicinein Sport, 21(2), 196-201. https:/ / doi.org/ 10.1016/ j.jsams. 2017.05.009

Varley, M. C., Jaspers, A., Helsen, W. F., \& Malone, J. J. (2017). Methodological considerations when quantifying highintensity effortsin team sport using global positioning system technology. International Journal of Sports Physiology and Performance, 12 (8), 1059-1068. https:/ / doi.org/ 10.1123/ ijspp. 2016-0534

Weston, M. (2018).Training load monitoring in eliteEnglish soccer: A comparison of practices and perceptions between coaches and practitioners. Science and Medicine in Football, 2(3), 216224. https:/ / doi.org/ 10.1080/ 24733938.2018.1427883 W hitehead, S. Till, K., Weaving, D., \& Jones, B. (2018). TheU se of Microtechnology to Quantify the Peak Match Demands of the Football Codes: A Systematic Review. Sports Medicine, 48(11), 2549-2575. https:/ / doi.org/ 10.1007/ s40279018-0965-6

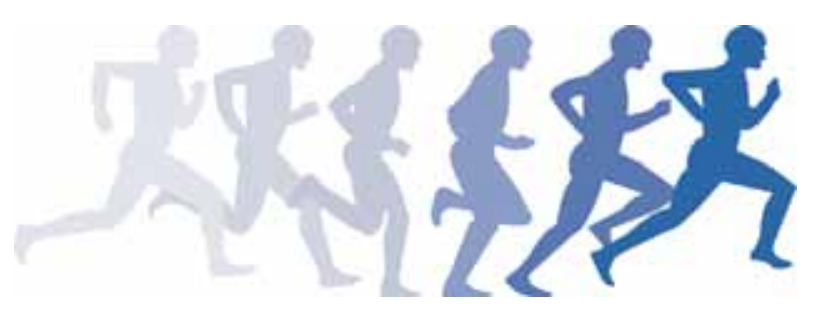

